\title{
Genetic susceptibility to chronic obstructive pulmonary disease in Koreans: combined analysis of polymorphic genotypes for microsomal epoxide hydrolase and glutathione S-transferase M1 and $\mathrm{T} 1$
}

\author{
Jae-Joon Yim, Gye Young Park, Choon-Taek Lee, Young Whan Kim, Sung Koo Han, \\ Young-Soo Shim, Chul-Gyu Yoo
}

\begin{abstract}
Background-Although smoking is the major causal factor in the development of chronic obstructive pulmonary disease (COPD), only 10-20\% of chronic heavy cigarette smokers develop symptomatic COPD which suggests the presence of genetic susceptibility. This genetic susceptibility to COPD might depend on variations in enzyme activities that detoxify cigarette smoke products such as microsomal epoxide hydrolase (MEPHX) and glutathione-S transferase (GST). As there is increasing evidence that several genes influence the development of COPD, multiple gene polymorphisms should be investigated to find out the genetic susceptibility to COPD.
\end{abstract}

Methods-The genotypes of 83 patients with COPD and 76 healthy smoking control subjects were determined by polymerase chain reaction (PCR) followed by restriction fragment length polymorphism (PCR-RFLP) for the mEPHX gene, and multiplex PCR for GST M1 and GST T1 genes. The frequencies of polymorphic genotypes of $\mathrm{mEPHX}$, GST M1, and GST T1 genes were compared both individually and in combination in patients with COPD and healthy smokers.

Results-No differences were observed in the frequency of polymorphic genotypes in exons 3 and 4 of $\mathrm{mEPHX}$, GST M1, and GST T1 genes between patients with COPD and healthy smokers. The frequencies of any combination of these genotypes also showed no differences between the COPD group and the control group.

Conclusions-Genetic polymorphisms in mEPHX, GST M1, and GST T1 genes are not associated with the development of COPD in Koreans.

(Thorax 2000;55:121-125)

Keywords: chronic obstructive pulmonary disease; microsomal epoxide hydrolase; glutathione-S transferase; genetics

Chronic obstructive pulmonary disease (COPD) is known to be the fourth leading cause of death ${ }^{1}$ and the only cause of death which is increasing. Although smoking is regarded as the most important causal factor, suggesting the importance of environmental factors, the fact that only $10-20 \%$ of chronic heavy cigarette smokers develop symptomatic COPD indicates the presence of genetic predisposing factors in its pathogenesis. ${ }^{2}$ Despite the clinical importance of COPD, few studies have been published about the genetic susceptibility. The $Z$ variant of $\alpha_{1}$ antitrypsin $\left(\alpha_{1}-\mathrm{AT}\right)$ is the best established genetic factor in the development of COPD. Patients with the homozygous form of this variant have a very high risk of developing emphysema at an early age if they smoke and are prone to rapid deterioration of their pulmonary function even without smoking. ${ }^{3}$ However, the incidence of the $\mathrm{Z}$ variant of $\alpha_{1}$-AT is too low to explain adequately the genetic predisposition to COPD in the general population. ${ }^{45}$ It has been proposed that genetic factors other than the $\mathrm{Z}$ variant of $\alpha_{1}$-AT such as $\alpha_{1}$-antichymotrypsin deficiency, $1 \mathrm{~F}$ homozygote of vitamin $\mathrm{D}$ binding protein, and blood group antigen $\mathrm{A}$, for example, may be involved in the pathogenesis of COPD. ${ }^{6-8}$

One possible reason why only a small proportion of smokers develop COPD might be genetic variation in the enzymes that detoxify cigarette smoke products. These enzymes include microsomal epoxide hydrolase (mEPHX), glutathione S-transferase (GST), and cytochrome p 450 1A1 (CYP1A1). mEPHX catalyses the hydrolysis of a wide range of exogenous arene and aliphatic epoxides to form water soluble dihydrodiols. ${ }^{9}$ Among seven polymorphic loci found in human mEPHX, Tyr/His 113 (exon 3) and His/Arg 139 (exon 4) variants have been suggested to be related to enzyme activity. Tyr 113/ Arg 139 variants were reported to have the fastest enzyme activity and His $113 /$ His 139 variants the slowest. ${ }^{10}$ It has recently been suggested that a slow metabolising form of mEPHX might be closely linked to the pathogenesis of COPD. ${ }^{11}$ GST is a complex supergene family of soluble isozymes which catalyse the nucleophilic attack of glutathione on a wide range of hydrophobic electrophiles. ${ }^{12}$ Among the isoenzymes of GST, homozygous null GST M1 genotype has been reported to have some association with the pathogenesis of lung cancer, ${ }^{13-15}$ bladder cancer, ${ }^{16}$ pituitary adenoma, ${ }^{17}$ and, particularly, emphysema. ${ }^{18}$ 
GST T1 conjugates glutathione and various potential carcinogens including halomethanes ${ }^{19}$ which are present in cigarette smoke, and its null type mutant has been suggested as a risk factor in colon cancer, ${ }^{20}$ myelodysplastic syndrome, ${ }^{21}$ meningioma, and astrocytoma. ${ }^{22}$ However, no association between COPD and the homozygous null genotype of GST T1 has been reported.

There is increasing evidence that several genes influence the development of COPD. When multiple genes are operating in the pathogenesis of disease, the influence of each gene might be relatively weak. Multiple gene polymorphisms should therefore be investigated to determine the genetic markers that predict the risk for developing COPD. However, most previous studies have compared the frequency of the genotype of each gene. We therefore studied the frequencies of genetic polymorphisms of mEPHX, GST M1, and GST T1 in patients with COPD and healthy subjects to determine whether multiple polymorphisms of these genes are linked to a genetic susceptibility to COPD.

\section{Methods}

SELECTION OF STUDY SUBJECTS

The study subjects comprised 83 patients attending the COPD clinic of Seoul National University Hospital and 76 healthy smokers who visited health centres for an annual check up. Inclusion criteria for COPD were as follows: chronic respiratory symptom and signs such as cough, breathlessness, wheeze; forced expiratory volume in one second $\left(\mathrm{FEV}_{1}\right)$ of less than $80 \%$ predicted; ratio of $\mathrm{FEV}_{1}$ to forced vital capacity (FVC) of 0.7 or less; $\mathrm{FEV}_{1}$ reversibility after inhalation of $200 \mu \mathrm{g}$ salbutamol of less than $12 \%$ of prebronchodilator $\mathrm{FEV}_{1}$. The patients with bronchial asthma were excluded on the basis of reversibility of airflow obstruction. In the healthy smoking group individuals with either abnormal pulmonary function or abnormal findings on chest radiography were excluded. Patients with malignant diseases were also excluded from both groups.

PCR-RESTRICTION FRAGMENT LENGTH

POLYMORPHISM (PCR-RFLP)

Informed consent was obtained from all subjects to donate their blood for genotyping. Using an InstaGene ${ }^{\mathrm{TM}}$ kit (BioRad, USA), DNA was extracted from $50 \mu \mathrm{l}$ whole blood and polymerase chain reaction followed by restriction fragment length polymorphism (PCR-RFLP) was performed to detect point mutations in exons 3 (Try/His 113, putative slow allele) and 4 (His/Arg 139, putative fast allele) of mEPHX genes as described previously. ${ }^{11}$ Primers used for the amplification of exons 3 and 4 were as follows.

Exon 3: 5'-GATCGATAAGTTCCGTTTC ACC-3', 5'-ATCCTTAGTCTTGAAGTGAG GAT-3'

Exon 4: 5'-ACATCCACTTCATCCACGT3', 5'-ATGCCTCTGAGAAGCCAT-3'

PCRs were carried out with a thermal cycler (PTC-100 ${ }^{\mathrm{TM}}$, M J Research Inc, USA) in PCR buffers (100 ng DNA, $1.5 \mathrm{mM} \mathrm{MgCl}_{2}$,
$10 \mathrm{mM}$ Tris $\mathrm{Cl}$ (pH 8.3), $40 \mathrm{mM} \mathrm{KCl}, 4 \%$ dimethyl sulphoxide, $200 \mathrm{mmol} / \mathrm{l}$ of each dNTP, $100 \mathrm{ng}$ primers, and 1 unit of Taq polymerase (Bioneer, Korea) in a final volume of $20 \mu \mathrm{l}$. For exon 3 amplification the steps consisted of 35 cycles of $52^{\circ} \mathrm{C}$ for 20 seconds, $72^{\circ} \mathrm{C}$ for 20 seconds, $94^{\circ} \mathrm{C}$ for 30 seconds, and $72^{\circ} \mathrm{C}$ for five minutes; for exon 4 the annealing temperature was $58^{\circ} \mathrm{C}$ but otherwise the steps were the same. The PCR products were digested with $E c o R \mathrm{~V}$ (exon 3 ) and $R s a \mathrm{I}$ (exon 4), respectively (Boehringer Mannheim $\mathrm{GmbH}$, Germany) which produce $140 \mathrm{bp}$ and $20 \mathrm{bp}$ fragments (exon 3 wild genotype) and $164 \mathrm{bp}$ and $46 \mathrm{bp}$ fragments (mutant homozygous type of exon 4 ). The fragments were then resolved on ethidium bromide stained 3\% NuSieve/agarose gel (FMG Bioproducts, USA) and transilluminated with UV light.

MULTIPLEX PCR

To detect deletion of the GST M1 and T1 genes we performed a multiplex PCR using the $\beta$ globulin gene as an internal control. The primer pairs for each gene were as follows:

GST M1: 5'-GAACTCCCTGAAAAGCTA AAGC-3', 5'-GTTGGGCTCAAATATACGG TGG-3'

GST T1: 5'-TTCCTTACTGGTCCTCAC ATCTC-3', 5'-CAGCTGCATTTGGAAGT GCTC-3'

$\beta$ globulin: 5'-CAACTTCATCCACGTTC ACC-3', 5'-GAAGAGCCAAGGACAGGTA C-3'

The PCR buffer was the same as that used for mEPHX gene amplification and PCR cycles consisted of 34 cycles of $94^{\circ} \mathrm{C}$ for 10 seconds, $58^{\circ} \mathrm{C}$ for 20 seconds, $72^{\circ} \mathrm{C}$ for $45 \mathrm{sec}-$ onds, and $72^{\circ} \mathrm{C}$ for five minutes. The products of the multiplex PCR (215 bp for GST M1, $480 \mathrm{bp}$ for GST T1, and $268 \mathrm{bp}$ for $\beta$ globulin) were separated by electrophoresis with ethidium bromide stained 3\% NuSieve/agarose gel (FMG Bioproducts, USA).

STATISTICAL ANALYSIS

The SAS statistical package was used in all analyses. The frequency of each genotype, the odds ratio (OR), and 95\% confidence interval (CI) were calculated by the Cochran-MantelHaenszel method. We tested whether age or smoking history might influence risk with the Cochran Mantel-Haenszel analysis of genotype effects by stratification of age and amount of smoking (age: $\leqslant 40,40-60,>60$; pack years of smoking: $\leqslant 15,15-30,>30)$.

\section{Results}

BASELINE CLINICAL CHARACTERISTICS OF STUDY SUBJECTS

Table 1 shows the baseline characteristics of the 159 study subjects. The $\mathrm{FEV}_{1}$ of the COPD group was significantly lower than that of the control group $(\mathrm{p}<0.01)$.

GENOTYPES OF MEPHX

The restriction PCR products of the mEPHX gene were of the expected size (fig 1). The differences in the frequencies of exon 3 and exon 
Table 1 Baseline characteristics of subjects

\begin{tabular}{lll}
\hline & $\begin{array}{l}\text { COPD group } \\
(n=83)\end{array}$ & $\begin{array}{l}\text { Control group } \\
(n=76)\end{array}$ \\
\hline M:F & $77: 6$ & $76: 0$ \\
$\begin{array}{l}\text { Median age (range) } \\
\text { Smoking }\end{array}$ & $66(42-82)$ & $48(27-72)$ \\
$\quad$ Never smoker & 4 & 0 \\
Ex-smoker & 51 & 19 \\
Current smoker & 28 & 57 \\
$\quad$ Median (range) pack years & $44(1-175)$ & $20(0.75-70)$ \\
Pulmonary functiont & & \\
FEV $(1)$ & $1.25(0.55)$ & $3.46(0.58)$ \\
FEV $_{1}$ (\% predicted) & $45.9(15.3)$ & $102.57(9.95)$ \\
$\quad<40 \%$ of predicted value & 29 & 0 \\
$40-59 \%$ of predicted value & 35 & 0 \\
60-79\% of predicted value & 19 & 0 \\
$>80 \%$ of predicted value & 0 & 76 \\
\hline
\end{tabular}

*Pack years of ex-smokers and current smokers.

†Numbers are mean (SD).

Exon 3

$162 \mathrm{bp} \rightarrow$ $140 \mathrm{bp} \rightarrow$

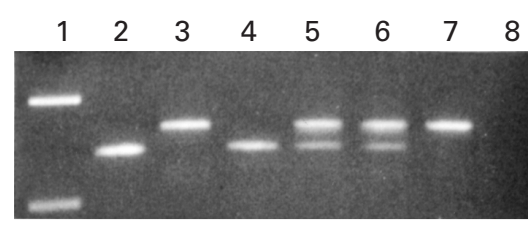

Exon 4

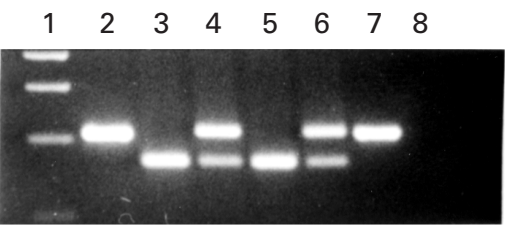

Figure 1 Patterns of PCR-RFLP for mEPHX gene. Top: the PCR products of exon 3 were digested with EcoR $V$ which cleaved wild genotype into $140 \mathrm{bp}$ and $20 \mathrm{bp}$ fragments. Lanes 1 and 8 are the DNA size marker and negative control, respectively; lanes 2 and 4 represent homozygous wild genotypes; lanes 3 and 7 homozygous mutant genotypes; and lanes 5 and 6 heterozygous genotypes. Bottom: the PCR products of exon 4 were digested with Rsa I which cleaved homozygous mutant genotype into $160 \mathrm{bp}$ and $46 \mathrm{bp}$ fragments. Lanes 1 and 8 are the DNA size marker and negative control, respectively; lanes 2 and 7 represent homozygous wild genotypes; lanes 3 and 5 homozygous mutant genotypes; and lanes 4 and 6 heterozygous genotypes.

4 mutant genotypes of mEPHX in the control and COPD groups were not significant $(\mathrm{p}=$ 0.86 in exon $3, p=0.19$ in exon 4 ; table 2 ). These results were not changed after adjusting for differences in the amount of smoking and age (data not shown) between the two groups.

GENOTYPES OF GST M1 AND T1

The PCR produced amplimers of the expected size (fig 2). The frequencies of the wild and null

Table 2 Distribution of mEPHX genotypes in patients with COPD and healthy subjects

\begin{tabular}{|c|c|c|c|}
\hline & $\begin{array}{l}\text { Homozygous wild } \\
\text { type }\end{array}$ & Heterozygous type & $\begin{array}{l}\text { Homozygous } \\
\text { mutant type }\end{array}$ \\
\hline \multicolumn{4}{|l|}{ Exon 3 polymorphism ${ }^{\star}$} \\
\hline Control $(\mathrm{n}=76)$ & $20(26 \%)$ & $24(32 \%)$ & $32(42 \%)$ \\
\hline COPD $(\mathrm{n}=83)$ & $24(29 \%)$ & $23(28 \%)$ & $36(43 \%)$ \\
\hline OR $(95 \% \mathrm{CI})$ & 1.0 & $0.80(0.35$ to 1.83$)$ & $0.94(0.44$ to 2.01$)$ \\
\hline $\begin{array}{l}\text { OR }(95 \% \mathrm{CI}) \text { smoking } \\
\text { adjusted }\end{array}$ & 1.0 & $0.86(0.32$ to 2.26$)$ & 1.08 (0.46 to 2.56$)$ \\
\hline \multicolumn{4}{|l|}{ Exon 4 polymorphism $†$} \\
\hline Control $(\mathrm{n}=76)$ & $57(75 \%)$ & $17(22 \%)$ & $2(2 \%)$ \\
\hline COPD $(n=83)$ & $59(71 \%)$ & $16(19 \%)$ & $8(10 \%)$ \\
\hline OR $(95 \% \mathrm{CI})$ & $0.26(0.06$ to 1.16$)$ & $0.30(0.05$ to 1.20$)$ & 1.0 \\
\hline $\begin{array}{l}\text { OR ( } 95 \% \text { CI) smoking } \\
\text { adjusted }\end{array}$ & $(0.03$ to 1.29$)$ & $0.12(0.01$ to 1.57$)$ & 1.0 \\
\hline
\end{tabular}

${ }^{\star} \mathrm{p}=0.86, \mathrm{tp}=0.19$ ( $\chi^{2}$ test $)$.

OR; odds ratio, $95 \% \mathrm{CI} ; 95 \%$ confidence interval.

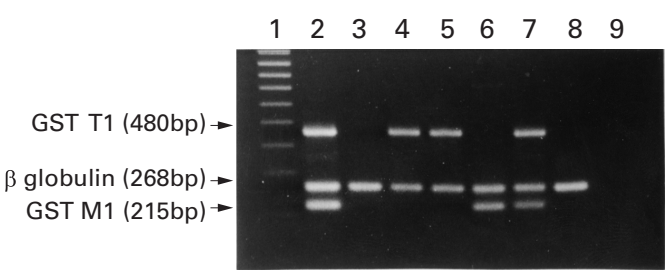

Figure 2 Patterns of multiplex PCR for GST M1 and GST T1 genes. $\beta$ globulin gene was used as an internal positive control. Lanes 1 and 9 are the size marker and negative control, respectively, lanes 2 and 7 represent wild genotypes for both GST M1 and GST T1 genes, and lanes 3 and 8 represent null genotypes for both GST M1 and GST T1 genes. Lanes 4 and 5 represent null genotypes for the GST M1 gene and wild genotypes for the GST T1 gene, and lane 6 is the wild genotype for the GST M1 gene and the null genotype for the GST T1 gene.

Table 3 Distribution of GST M1 and GST T1 genotypes in patients with COPD and healthy subjects

\begin{tabular}{lll}
\hline & Wild type & Null type \\
\hline GST M1* & & \\
Control $(\mathrm{n}=76)$ & $27(35 \%)$ & $49(65 \%)$ \\
COPD $(\mathrm{n}=83)$ & $36(43 \%)$ & $47(57 \%)$ \\
OR $(95 \% \mathrm{CI})$ & 1.0 & $1.39(0.73$ to 2.64$)$ \\
OR $(95 \% \mathrm{CI})$ smoking & 1.0 & $1.21(0.58$ to 2.51$)$ \\
adjusted & & \\
GST T1 & & \\
Control $(\mathrm{n}=76)$ & $29(38 \%)$ & $47(62 \%)$ \\
COPD $(\mathrm{n}=83)$ & $37(45 \%)$ & $46(55 \%)$ \\
OR $(95 \% \mathrm{CI})$ & 1.0 & $1.30(0.69$ to 2.46$)$ \\
OR $(95 \% \mathrm{CI})$ smoking & 1.0 & $1.23(0.60$ to 2.53$)$ \\
adjusted & & \\
\hline${ }_{\mathrm{p}}=0.31,+\mathrm{p}=0.67\left(\chi^{2}\right.$ test $)$. &
\end{tabular}

types of GST M1 and T1 were similar, even after adjusting for differences in age (data not shown) or amount of smoking in the two groups (table 3 ).

COMBINED ANALYSIS OF GENOTYPES OF MEPHX, GST M1, AND GST T1

We analysed the genotypes of mEPHX, GST $M 1$, and GST T1 in combination to evaluate whether combination of these genotypes is associated with the development of COPD. The frequencies of both the homozygous mutant in exon 3 and the homozygous wild type in exon 4 of the mEPHX gene, which represents the putative slow allele as described previously, ${ }^{11}$ were $38 \%$ and $28 \%$ in the control and COPD groups, respectively $(\mathrm{p}=0.38)$. The frequency of the null genotypes of both GST M1 and GST T1 in patients with COPD $(34 \%)$ was not very different from that of the control group (38\%). The combined genotypes of the homozygous mutant in exon 3 and the homozygous wild type in exon 4 of the mEPHX gene with the null genotypes of both GST M1 and GST T1 seemed to be defective in the detoxification of smoke products. However, the frequency of this combined genotype was the same in both groups $(11 \%$, table 4).

\section{Discussion}

There is likely to be a complex interplay between environmental and genetic factors in the development of COPD. However, the pathogenesis of COPD is still poorly understood at a molecular level. One possible reason that only a small proportion of smokers develop COPD might be genetic variations in 
Table 4 Distribution of mEPHX, GST M1, and GST T1 genotypes in combination

\begin{tabular}{|c|c|c|}
\hline \multicolumn{3}{|c|}{ Frequency of putative slow phenotype for mEPHX ${ }^{\star}$} \\
\hline & Both slow genotype & Others \\
\hline Control $(n=76)$ & $29(38 \%)$ & $47(62 \%)$ \\
\hline $\operatorname{COPD}(\mathrm{n}=83)$ & $23(28 \%)$ & $60(72 \%)$ \\
\hline OR $(95 \% \mathrm{CI})$ & 1.0 & $0.74(0.38$ to 1.45$)$ \\
\hline OR $(95 \% \mathrm{CI})$, smoking adjusted & 1.0 & $0.70(0.33$ to 1.48$)$ \\
\hline \multicolumn{3}{|c|}{ Frequency of null genotypes in both GSTM1 and T1 genes } \\
\hline & Both null genotype & Others \\
\hline Control $(n=76)$ & $29(38 \%)$ & $47(62 \%)$ \\
\hline COPD $(n=83)$ & $28(34 \%)$ & $55(66 \%)$ \\
\hline OR $(95 \% \mathrm{CI})$ & 1.0 & $0.83(0.43$ to 1.58$)$ \\
\hline OR (95\% CI), smoking adjusted & 1.0 & $1.04(0.51$ to 2.12$)$ \\
\hline \multicolumn{3}{|c|}{ Frequency of putative slow phenotype of mEPHX and both null genotype of GST M1 and T1 } \\
\hline & $\begin{array}{l}\text { Putative slow pheno } \\
\text { (mEPHX) two null } \\
\text { genotypes }\end{array}$ & Others \\
\hline Control $(\mathrm{n}=76)$ & $8(11 \%)$ & $68(89 \%)$ \\
\hline COPD $(\mathrm{n}=83)$ & $9(11 \%)$ & $74(89 \%)$ \\
\hline OR $(95 \% \mathrm{CI})$ & 1.0 & $1.03(0.38$ to 2.84$)$ \\
\hline OR $(95 \% \mathrm{CI})$, smoking adjusted & 1.0 & $1.28(0.44$ to 3.67$)$ \\
\hline
\end{tabular}

${ }^{\star}$ Homozygous mutant genotype in exon 3 and homozygous wild type in exon 4 of mEPHX gene $\mathrm{tp}>0.05$. in China cannot be entirely accounted for by lower tobacco consumption, ${ }^{24}$ different genetic factors might influence the development of COPD in different ethnic groups. Gene frequency is different between different racial groups, which may explain the differences in association between gene polymorphism and COPD in the various studies. Ethnic differences could therefore be accounted for by the differing frequencies of genes relevant to pathogenesis. In our study the frequencies of each genotype in exon 3 of $\mathrm{mEPHX}$ and GST T1 were significantly different from those found in western countries. In the genotype of mEPHX exon 3 the proportion of homozygous mutant (putative slow allele) in our healthy control group was much larger than that reported by Smith et al (42\% versus 6\%). ${ }^{11}$ The frequency of the null type GST T1 in our control group was also higher than in Caucasians (62\% versus $20.4 \%) .^{25}$ The frequency of genotypes in MEPHX exon 4 and GST M1 in our study, however, was not much different from that found in western countries. ${ }^{1126}$ The discrepancy between these studies could therefore be accounted for, at least in part, by the racial difference in gene frequency.

The low prevalence of COPD in Korea, ${ }^{27}$ despite the higher frequencies of the putative slow phenotype of mEPHX and null type GST T1 compared with western countries, suggests that polymorphisms of these genes are not associated with the pathogenesis of COPD in Koreans.

In a complex polygenic disease such as COPD it is likely that multiple genes are operating and the genetic susceptibility may be dependent on the coincidence of several gene polymorphisms acting together. Polymorphism of each gene may therefore impart only a small relative risk of COPD and it is likely that the coincidence of many polymorphisms will be important in its pathogenesis. We analysed the genotypes of mEPHX, GST M1, and GST T1 genes in combination to find out the association between these combined genotypes and development of COPD. However, none of the combinations showed a different frequency between the two groups, which suggests that polymorphisms of these three genes are not a risk factor for COPD or the influence of the genes is too weak to explain the genetic susceptibility to COPD.

The limitations of this study are lack of sex and age matching between the two groups and the fact that only a few genes involved in the detoxification of smoke products were studied. Because gene frequencies in the general population do not vary according to sex in general, lack of sex matching might not affect the results of this study. However, as some of the control subjects could be destined to develop COPD in the future, the fact that the controls were younger than the patients with COPD in this study could have reduced the effects of polymorphic genotypes of the enzymes in the development of COPD.

In conclusion, genetic polymorphisms of mEPHX, GST M1, and GST T1 genes, both individually and in combination, were not was also reported from Japan (Kimihiro Takeyabu, personal communication). Ethnic differences in the prevalence of COPD are very difficult to separate from environmental factors. However, as the low prevalence of COPD

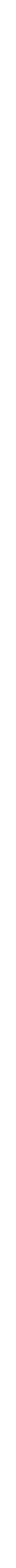


associated with the development of COPD in a Korean population. In future studies multiple gene polymorphisms including other candidate genes in parallel and new candidate genes should be investigated to identify the genetic markers that could predict the risk for development of COPD.

We thank Tae Kyun Kim for his skilful technical assistance.

1 Mortality patterns: preliminary data, United States, 1996 $M M W R$ 1997;46:941-8.

2 Bascom R. Differential susceptibility to tobacco smoke: possible mechanisms. Pharmacogenetics 1991;1:102-6.

3 Black LF, Kueppers F. $\alpha_{1}$ antitrypsin deficiency in nonsmokers. Am Rev Respir Dis 1978;117:421-8.

4 Sveger T. Liver disease in $\alpha_{1}$ antitrypsin deficiency detected by screening of 200,000 infants. N Engl F Med 1976;294: $1316-21$

5 O'Brien ML, Buist NRM, Murphet WH. Neonatal screening for $\alpha_{1}$ antitrypsin deficiency. F Pediatr 1978;92:1006 10 .

6 Erikson S, Lindmark B, Lilja H. Familial $\alpha_{1}$ antichymotrypsin deficiency. Acta Med Scand 1986;220:447-53.

7 Kauffman F, Kleisbauer J-P, Cambon-de-Mouzon A, et al. Genetic markers in chronic airflow limitation: a genetic Genetic markers in chronic airflow limitation: a genetic

8 Beatty TH, Menker HA, Cohen BH, et al. Risk factors associated with longitudinal change in pulmonary function. $\mathrm{Am}$ ciated with longitudinal change
Rev Respir Dis 1984;129:660-7.

Rev Respir Dis 1984;129:660-7.
9 Watabe T, Kanai M, Isobe M, et al. The hepatic biotransformation of delta 5 steroids to 5 alpha, 6 beta-glycols via alpha- and beta-epoxides. F Biol Chem 1981;256:2900-7.

10 Hasset C, Aicher L, Sidhu JS, et al. Human microsoma epoxide hydrolase: genetic polymorphism and functional expression in vitro of amino acid variants. Human Mo Genet 1994;3:421-8.

11 Smith CAD, Harrison DJ. Association between polymorphism in gene for microsomal epoxide hydrolase and susceptibility to emphysema. Lancet 1997;350:630-3.

12 Ketterer B, Meyer DJ, Clark AG. Soluble glutathione transferase isoenzymes. In: Sies H, Ketterer B, eds. Glutathione ferase isoenzymes. In: Sies H, Ketterer B, eds. Glutat

13 Seidegard J, Pero RW, Miller DG, et al. A glutathione S-transferase in human leukocytes as a marker for the susS-transferase in human leukocytes as a marker for the sus-
ceptibility to lung cancer. Carcinogenesis 1986;7:751-3.

14 Nazar-Stewart V, Motulsky AG, Eaton DL, et al. The glutathione $S$ transferase $\mu$ polymorphism as a marker for the susceptibility to lung carcinoma. Cancer Res 1993;53 2313-8.
15 Hirvonen A, Husgafvel-Pursianen K, Anttila S, et al. The GST M1 null genotypes as a potential risk modifier for squamous cell carcinoma of the lung. Carcinogenesis 1993;14:1479-81.

16 Bell DA, Taylor JA, Paulson DF, et al. Genetic risk and carcinogen exposure: a common inherited defect of the carcinogen-metabolism gene glutathione S-transferase M1 carcinogen-metabolism gene glutathione S-transferase M1 cer Inst 1993;85:1159-64.

17 Fryer AA, Zhao CL, Alldersea J, et al. The glutathione S-transferases: polymerase chain reaction studies on the frequency of the GSTM1 0 genotype in patients with pituitary adenoma. Carcinogenesis 1993;14:563-6.

18 Harrison DJ, Cantlay AM, Rae F, et al. Frequency of glutathione S-transferase M1 deletion in smokers with emphysema and lung cancer. Hum Exp Toxicol 1997;16: 356-60.

19 Pemble S, Schroeder KR, Spence SR, et al. Human glutathione S-transferase theta: cDNA cloning and the characterization of a genetic polymorphism. Biochem f 1994;300: 271-6.

20 Chenevix-Trench G, Young J, Coggan M, et al. Glutathione S-transferase M1 and T1 polymorphisms: susceptibility to colon cancer and age of onset. Carcinogenesis 1995;16: colon canc

21 Chen H, Sandler DP, Tayor JA, et al. Increased risk for myelodysplastic syndromes in individuals with glutathione transferase theta 1 gene defect. Lancet 1996;347:295-7.

22 Elexpuru J, Buxton N, Kandula V, et al. Susceptibility to astrocytoma and meningioma: Influence of alleism at glutathione S-transferase (GST T1, GST M1) and cytochrome P-450 (CYP2D6) loci. Cancer Res 1995;55: cytochrome $4237-9$.

23 Cantlay AM, Smith CAD, Wallace WA, et al. Heterogenous expression and polymorphic genotype of glutathione S-transferases in human lung. Thorax 1994;49:1010-4.

24 Buist AS, Vollmer WM, Wu Y, et al. Effects of cigarette smoking on lung function in four population samples in the People's Republic of China. The PRC-US Cardiovascular and Cardiopulmonary Epidemiology Research Group. Am f Respir Crit Care Med 1995;151:1393-400.

25 Nelson HH, Wiencke JK, Christiani DC, et al. Ethnic differences in the prevalence of the homozygous deleted genotype of glutathione S-transferase theta. Carcinogenesi 1995;16:1243-5.

26 Chen CL, Liu Q, Relling MV. Simultaneous characterization of glutathione S-transferase $\mathrm{M} 1$ and $\mathrm{T} 1$ polymorphisms by polymerase chain reaction in American whites phisms by polymerase chain reaction in Am

27 Ministry of Health and Welfare. Deaths by causes. In: Yearbook of health and welfare statistics. Seoul: Ministry of Health and Welfare, 1998: 50-84. 